\title{
Kick-Off Point (KOP) and End of Buildup (EOB) Data Analysis in Trajectory Design
}

\author{
Novrianti ${ }^{1}$, Rycha Melisa ${ }^{1}$, Rafhie Adrian ${ }^{1}$ \\ ${ }^{1}$ Department of Petroleum Engineering, Universitas Islam Riau, JIn. Kaharuddin Nasution No. 113, Pekanbaru, Riau
}

* Corresponding author : novrianti@eng.uir.ac.id

Tel.: +81-22-2000489

Received: May 2, 2017. Revised : May 25, 2017, Accepted: May 31, 2017, Published: 1 June 2017

DOI: 10.24273/jgeet.2017.2.2.302

Abstract

Well $X$ is a development well which is directionally drilled. Directional drilling is choosen because the coordinate target of Well $\mathrm{X}$ is above the buffer zone. The directional track plan needs accurate survey calculation in order to make the righ track for directional drilling. There are many survey calculation in directional drilling such as tangential, underbalance, average angle, radius of curvature, and mercury method. Minimum curvature method is used in this directional track plan calculation. This method is used because it gives less error than other method. Kick-Off Point (KOP) and End of Buildup (EOB) analysis is done at $200 \mathrm{ft}, 400 \mathrm{ft}$, and $600 \mathrm{ft}$ depth to determine the trajectory design and optimal inclination. The hole problem is also determined in this trajectory track design. Optimal trajectory design determined at $200 \mathrm{ft}$ depth because the inclination below 350 and also al ready reach the target quite well at 1632.28 ft TVD and 408.16 AHD. The optimal inclination at $200 \mathrm{ft} \mathrm{KOP}$ depth because the maximum inclination is $18.87^{\circ}$ which is bel ow 35 . Hole problem will occur if the trajectory designed at $600 \mathrm{ft}$. The problems are stuck pipe and the casing or tubing will not able to bend.

Keywords: Directional Drilling, Trajectory, Kick of Point, End of Buildup, Minimum of Curvature

\section{Introduction}

Directional drilling is a technique to deflect the wellbore and then directed to desired target in the formation al so not located vertically below the well. In the beginning, directional drilling is used to correct the turn that occured at the vertical hole. (Grace BS, Widrajat, AK, 2015) (Adams, 1985) (Rubiandini, 2012). Actually in drilling always desirable a vertical hole because of The operation cost is cheaper and easier to implement. But not all Drilling can be done vertically certain reasons, so it should be directional drilling.(Grace BS, Widrajat, AK, 2015) There are causative factors in directional drilling: (Bourgoyne, AT, 1991)(Inglis, 2005)

1. Topograph Factor

a. Productive formation is located below the lake or river.

b. Productive formation is located below the buildings.

2. Geological Factor

a. Salt dome

b. Faults

3. Economic Factor

a. Land acquisition fee

b. Equipment removal

c. Waste treatment

4. Multi-lateral cluster system

5. Cluster System

6. Blowout prevention by relief well.

7. Sidetracking
There are 3 common types of track in directional drilling: (Rabia, 2002),(Adila, Maruti Tiffani, 2015) (Mitchell, 1995)(Omar Farah, 2013)(Mitchell and Miska, 2011).

\section{a. Build Hold}

The turning point depth in Kick-Off Point located not to far from the surface (shallow). The deflection of hole is done by increasing the slope and corresponded to Buildup Rate (BUR) that has been planned.

Kick of Point (KOP) is the point or depth where the well track will be distorted until it reaches the specified inclination angle. (Hamid and Setiawan, 2015)

b. Build Hold and Drop

This type is used in certain condition, for example at salt dome or while sidtracking. The deflection of hole is done far from the surface casing, and the the slope is mainatained until reach the target. The well with the deep turning point or Kick-Off Point (KOP) have certain deficiency, there are:

1. The formation may be harder and is hard to deflect.

2. Tripping will be more often to replace Bottom Hole Assembly (BHA) while turning.

3. Buildup Rate will be uncontrolable.

c. Build Hold Partial Drop and Hold

First, it will be same with the deflection in the shallow depth but then it will be deflected 
again into vertical. As for the selection for the type of drilling based on coordinate between sufrace location and the target location or the desired formation.

After the plan and the drilling operation is done, the measurement of slope for each depth and the direction of borehole (survey) are executed. If the points are deviated, borehole will be directed to the point that already set before. There are many methods that can be used to determine suface point coordinates, tangential, balance tangential, average angle, radius of curvature, minimum of curvature, and mercury method (Inglis, 2005)(Zaremba, 1973) (Wilson, 1968)(Sawaryn and Thorogood, 2005). The cal culation of each methods based on measurement of 3 kinds of parameter. There are, depth of well (MD), the alteration of slope (I), and the direction angle (A) which are written on the survey equipment. The first reference to the minimum curvature directional survey calculation method is credited to Mason and Taylor in 1972.(Sawaryn and Thorogood, 2005)(Taylor and Mason, 2013) Minimum of curvature method seperate 2 intervals where the upper interval and lower interval. For the upper interval, inclination angle and azimuth is being used at the initial point. For the lower interval, inclination angle and azimuth is being used at the end of point. Minimum of curvature method can be seen in the fig. 1 below:

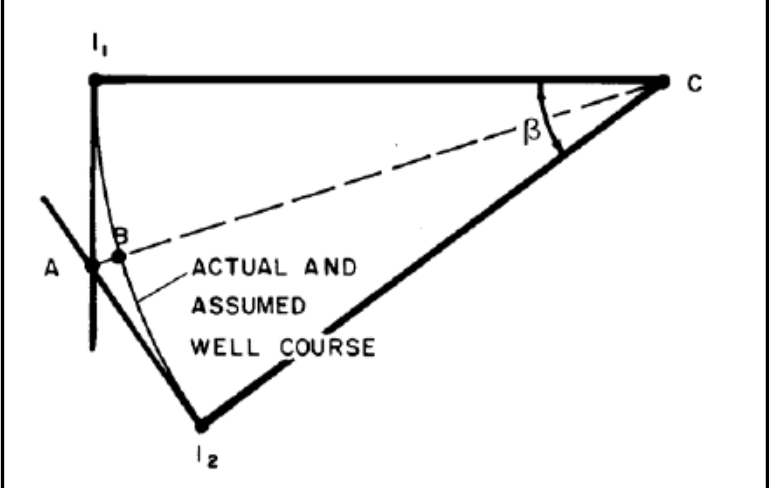

Fig 1. Minimum of Curvature Method

In this study, minimum of curvature method is used in the calculation of well track plan in well X. This method is used because it will gives the lower error than other method. Besides that, to determine the trajectoory design and optimal inclination analysis for the Kick-Off Point (KOP) and End of Buildup (EOB) is done by using 3 type of sesitivities based on depth, there are $200 \mathrm{ft}, 400 \mathrm{ft}$, and $600 \mathrm{ft}$ depth.

\section{Material and Methods}

In well trajectory design, the maximum inclination angle, target distance, BUR, and azimuth must be determined in the first place. The formulas used are : a. Target Direction

$$
d=\tan ^{-1} \frac{b}{c}
$$

b. Target Distance $\left(\mathrm{D}_{2}\right)$

$$
\begin{aligned}
& a^{2}=b^{2}+c^{2} \\
& a=\sqrt{b^{2}+c^{2}}
\end{aligned}
$$

c. Build Radius

$$
\begin{aligned}
& B U R=\frac{5729,58}{R} \\
& R=\frac{5729,58}{B U R}
\end{aligned}
$$

d. Maximum Inclination

$$
\begin{gathered}
\angle D O C=\tan ^{-1}\left(\frac{D C}{D O}\right) \\
O C=\frac{D O}{\cos \angle D O C} \\
\angle B O C=\cos ^{-1} \frac{R}{O C} \\
\angle B O D=\angle B O C+\angle D O C \\
\theta=90^{\circ}-\angle B O D
\end{gathered}
$$

e. $E O B M D$

$$
\mathrm{EOB} M \mathrm{MD}=V 1+\left(\frac{\theta}{B U R} x 100\right)
$$

Trajectory design parameters are calculated by using minimum of curvature method. The formulas are :

$$
R F=\left(\frac{2}{D L}\right) \tan \left(\frac{D L}{2}\right)
$$

a.

$D L=\cos \left(I_{2}-I_{1}\right)-\sin I_{1} \sin I_{2}\left(1-\cos \left(A_{2}-A_{1}\right)\right)$

b.

$$
\Delta T V D=\frac{\Delta M D}{2}\left(\cos I_{1}+\cos I_{2}\right) R F
$$

c. Measured Depth (ft) $\frac{\text { InklinationB }- \text { InklinationA }}{B U R}$

d. Closure distance $={\sqrt{N^{2}+E}}^{2}$

$$
\begin{aligned}
& \Delta N=\frac{\Delta M D}{2}\left(\sin I_{1} \cos A_{1}+\sin I_{2} \cos A_{2}\right) R F \\
& \Delta E=\frac{\Delta M D}{2}\left(\sin I_{1} \sin A_{1}+\sin I_{2} \sin A_{2}\right) R F
\end{aligned}
$$


Trajectory design and optimal inclination is done by analyze the Kick-Off Point (KOP) and End of Buildup (EOB) at $200 \mathrm{ft}, 400 \mathrm{ft}$, and $600 \mathrm{ft}$ depth. The profile data of well $X$ that being used in trajectory and incliatnin design can be seen in the table 1 .

Table 1. Well Profile

\begin{tabular}{|c|c|}
\hline Location Name & Sumur RA \\
\hline Classification & Development \\
\hline Tipe Well & Directional \\
\hline Total Depth & $2000 \mathrm{ft}$ MD \\
\hline \multirow{2}{*}{ Coordinate Surface } & N 040'12,76"' \\
\hline & E $102^{\circ} 4^{\prime} 33^{\prime \prime}$ \\
\hline Coordinate & N 040'9,73" / -304,37 ft N \\
\hline Target & E $102^{\circ} 4^{\prime} 33^{\prime \prime} / 271,48 \mathrm{ft}$ E \\
\hline Target Formation & 1650'sd / $1632.3 \mathrm{ft}$ TVD \\
\hline
\end{tabular}

\section{Results and Discussion}

The coordination of target, target distance, and azimuth that used in drilling track design in well $X$ can be seen in fig. 2. below

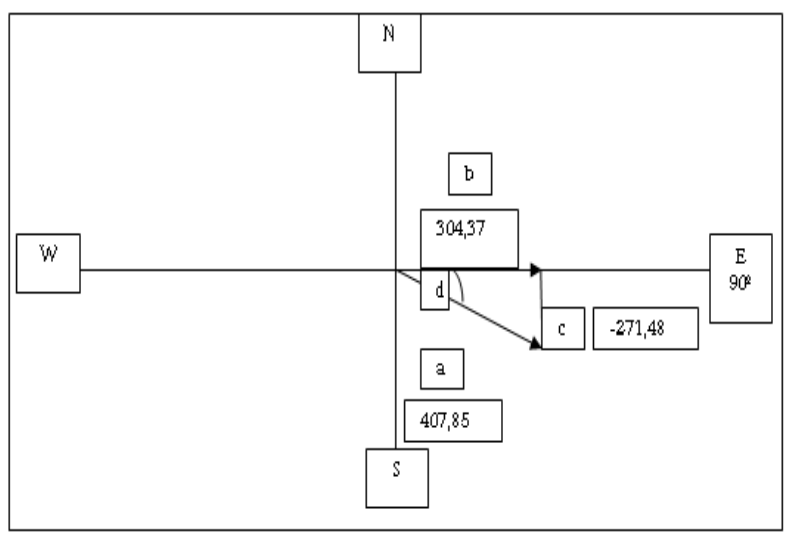

Fig 2. Plan View

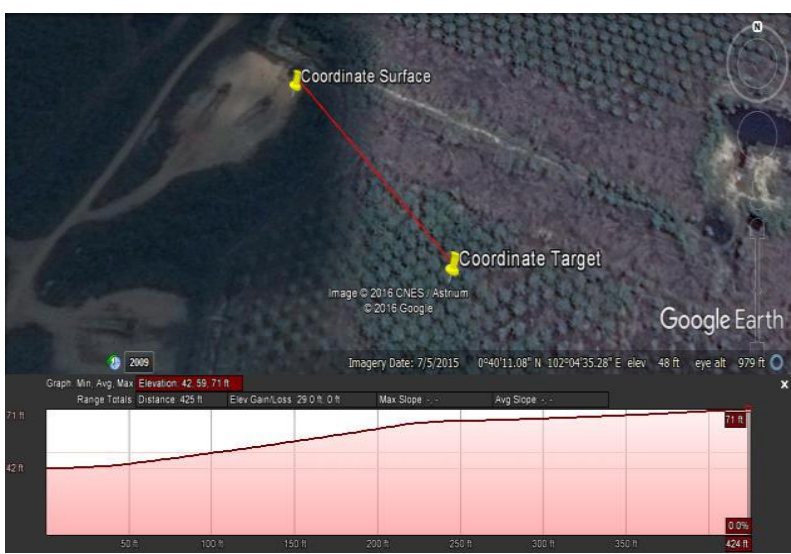

Fig 3. Target Coordinate

azimuth which is the direction of drilling it self. $a$ is the horizontal displacement, $b$ and $c$ is the drilling target coordination and $d$ is the azimuth value and drilling direction.
Trajectory design of well $X$ at $200 \mathrm{ft} \mathrm{KOP}$

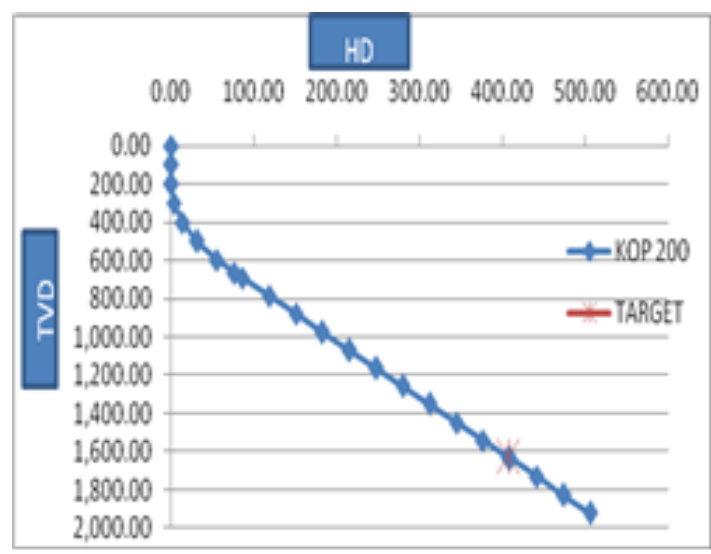

Fig 4. Trajectory Design at $200 \mathrm{ft} \mathrm{KOP}$

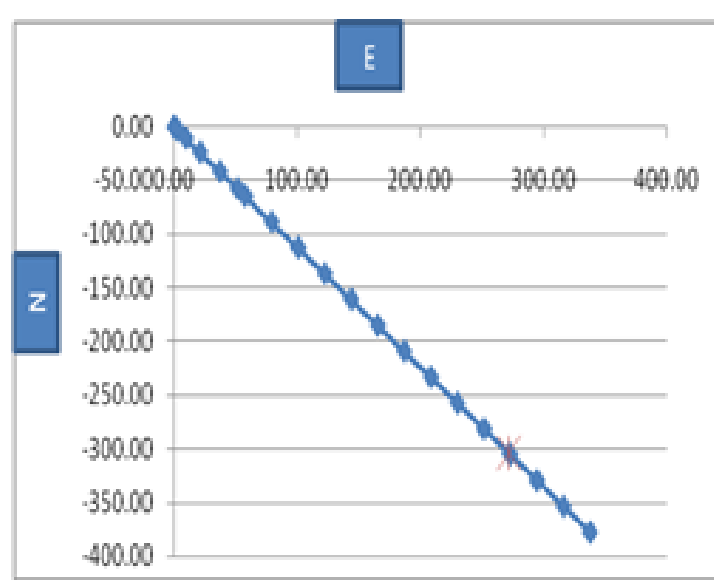

Fig 5. Vertically Track Direction

In the drilling track design catogory, the good track with $200 \mathrm{ft}$ KOP already assumed as good criteria because the inclination is $18.87^{\circ}$, which is the suitable value when the inclination in drilling opration si less than 35 o because in other well data if the inclination is more than 350 will caused the casing is unable to bend or the it will caused casing failure because the casing will break. The result in the $200 \mathrm{ft} \mathrm{KOP}$ are $1632.28 \mathrm{ft}$ TVD and $408.16 \mathrm{ft}$ AHD, when with the $200 \mathrm{ft}$ KOP it will reach the.target well because the desired target is 1632.3 $\mathrm{ft}$ and $408.75 \mathrm{ft}$ AHD.

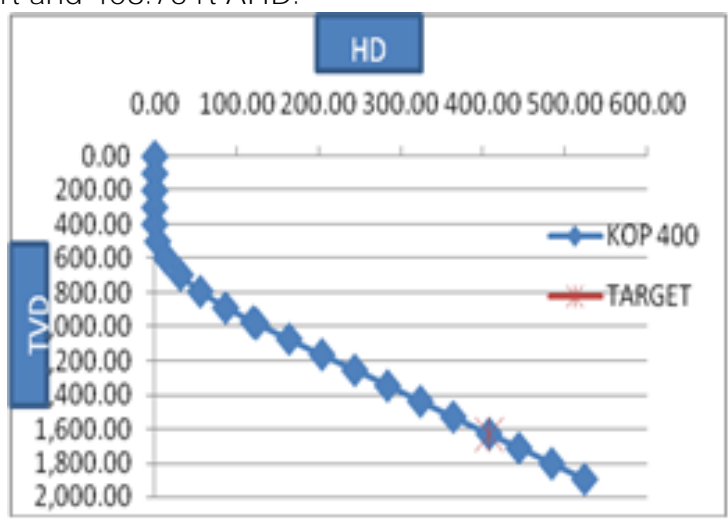

Fig 6. Trajectory design at $400 \mathrm{ft} \mathrm{KOP}$ 


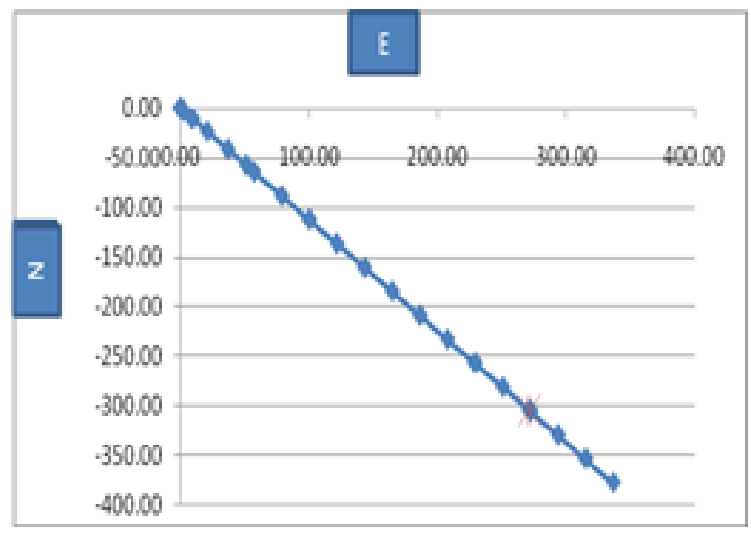

Fig 7. Direction of Vertical Track

Kick-Off Point determinated at $400 \mathrm{ft}$ depth in well $X$ has $23.62^{\circ}$ inclination, the target depth reached at $1632.41 \mathrm{ft}$ TVD and $407.92 \mathrm{ft}$ AHD. The good criteria is at $400 \mathrm{ft}$ KOP because the incl ination is below 350

HD

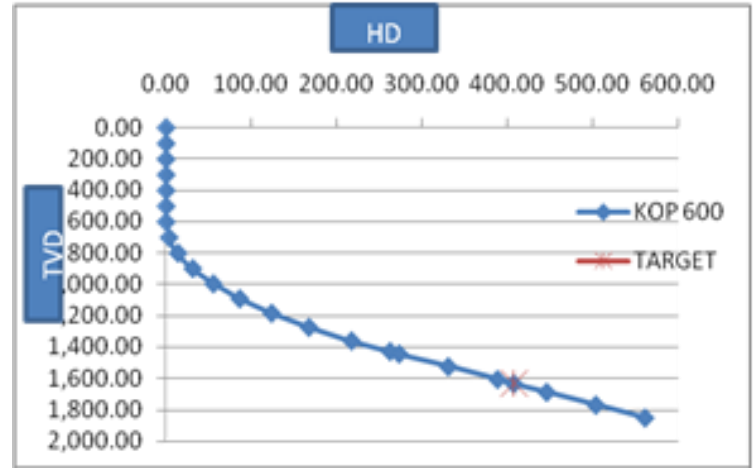

Fig 8. Trajectory Design at $600 \mathrm{ft} \mathrm{KOP}$

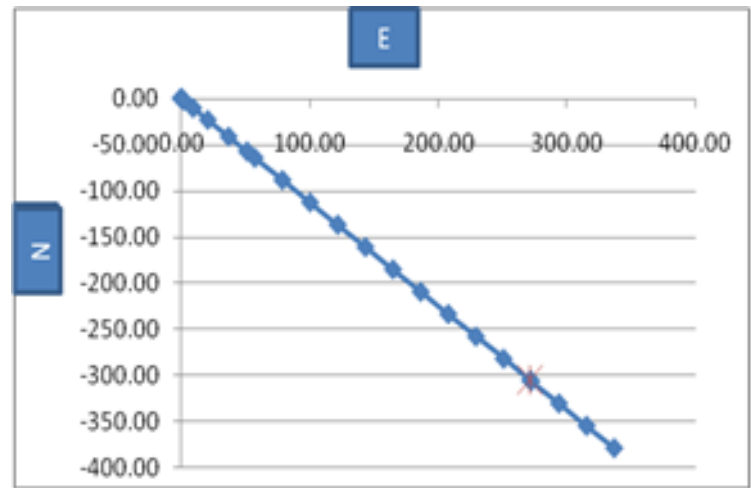

Fig 9. Direction of Vertical Track

At $600 \mathrm{ft}$ KOP the maxumum inclination angle is 35.26 , the target depth at $1632,43 \mathrm{ft}$ TVD and $407.99 \mathrm{ft}$ AHD. This depth has large the maximum incliation angle and its capability to reach the target will not be at maximum effort and if the KOP is too deep it will be reach the hard formation so the track will be hard to deflect, then it will be caused stuck pupe when tripping out because the inclination is too large. When the maxumum inclination angle is too large it also cause casing failure or tubing failure when installation, and the inability to maintain when bent. Because when a drillstring need to be bent or deflected at $600 \mathrm{ft}$ sharply to reach desired target. Because in drilling track design must consider the probability of the drillstring to be bent. If the drillstring passed its limit to be bent, the drillstring will be break.

\section{Conclusion}

Acccording to the drilling track design to the effect of KOP and EOB depth selecton in well $X$, the conclusion are:

1. Optimal trajectory design at $200 \mathrm{ft} \mathrm{KOP}$ because it gives the inclination below $35^{\circ}$ and it will reach the target very well at $1632.28 \mathrm{ft} \mathrm{TVD}$ and $408.16 \mathrm{ft}$ AHD.

2. Optimal inclination at $200 \mathrm{ft}$ KOP because the maximum inclination angle is $18.87^{\circ}$, which is good.

3. Hole problem that will occured if the trajectory design at $600 \mathrm{ft}$ are stuck pipe and inability of drillstring to be bent.

\section{References}

Adams, N.J., 1985. Drilling Engineering. Tulsa.

Adila, Maruti Tiffani, W.A., 2015. Perencanaan Lintasan dan Analisis Pembebanan pada lubang 81/2 sumur FA - 12 Lapangan A. Semin. Nas. Cendikiawan 267-275.

Bourgoyne, AT, K.M.M., 1991. Drilling Engineering.

Grace BS, Widrajat, AK, H., 2015. Perbandingan Lintasan Pemboran Berarah dengan Berbagai Metode Perhitungan Pada Sumur G- 12 Lapangan G I, 446-454.

Hamid, A., Setiawan, A., 2015. Evaluasi Lintasan Pemboran Berarah dengan metode Minimum of Curvature pada sumur $X$ Lapangan $Y$ Petrochina Internasional 58-64.

Inglis, T., 2005. Directional Drilling, Encyclopedia of Hydrocarbons - Volume I. doi:10.2118/7835MS

Mitchell, R.F., Miska, S.Z, 2011a. Fundamentals of Drilling Engineering.

Mitchell, R.F., Miska, S.Z., 2011b. Fundamentals of Drilling Engineering, Society of Petroleum Engineers Journal February.

Mitchell, Wi., 1995. Oil well drilling engineering handbook, 10 th Edit. ed. USA.

Omar Farah, F., 2013. Directional Well Design, Trajectory and Survey Calculations, With a Case Study in Fiale, Asal Rift, Djibouti.

Rabia, H., 2010. Well Engineering \& Construction 248.

Rubiandini, R., 2012. Teknik Operasi Pemboran I.pdf. Bandung.

Sawaryn, S.J., Thorogood, J.L., 2005. A Compendium of Directional Calculations Based on the Minimum Curvature Method. SPE Drill. Complet. 20, 24-36. doi: 10.2118/84246-PA

Taylor, H.L., Mason, M.C., 2013. A Systematic Approach to Well Surveying Calculations. Soc. Pet. Eng. J. 12, 474-488. doi: 10.2118/3362-PA

Wilson, G.J., 1968. An Improved Method for Computing Directional Surveys. J. Pet. Technol. 20. doi:10.2118/1992-PA 